\title{
Fermentative Ability of Wheat Flour and Watermelon Puree Citrullus Lanatus (Thunb) Mixture Usable in Bread Making: a Preliminary Study
}

\author{
Mamadou Sadji ${ }^{1}$, Penelope M Perkins-Veazie ${ }^{2}$, Ndèye Fatou Ndiaye ${ }^{1}$, Guoying MA ${ }^{2}$, Chekna Zongo ${ }^{3}$, Yves Traore $^{3}$,
} Mohamadou Diop Sall ${ }^{4}$ and Alfred Traore ${ }^{3}$

${ }^{1}$ Institut de Technologie Alimentaire (ITA), Route des Pères Maristes, Hann, Dakar BP 2765, Senegal

${ }^{2}$ Plant for Human Health Institute, North Carolina State University, North Carolina Research Campus, Suite 1329, 600 Laureate Way, Kannapolis, NC 28081, USA

${ }^{3}$ Centre de Recherche en Sciences Biologiques Alimentaires et Nutritionnelles, Université de Ouagadougou, 03 BP 7131 , Burkina Faso.

${ }^{4}$ Ecole Supérieure Polytechnique, Université Cheikh Anta Diop, BP 5085, Dakar Fann, Senegal

Received: 7 November, 2019; Accepted: 19 December, 2019; Published: 23 December, 2019

*Corresponding author: Mamadou SADJI, Affiliation: Institut de Technologie Alimentaire, Route des Pères Maristes, Hann, Dakar BP 2765, Senegal, Tel: (221) 7766659 89, Fax: (221) 83282 95, E-mail: msadji@ita.sn

\section{Abstract}

This study investigated the processing quality of watermelon puree in bread making. A mixture composed of wheat flour (95\%) and puree from "Kaolack" watermelon variety (5\%) (MWF-PKW) was made to evaluate its fermentative ability. Results showed that the rheological properties of MWF-PKW were satisfactory.

The maximum development of the dough, $\mathrm{Hm}(81.9 \mathrm{~mm})$ was close to that of the reference (100\% wheat flour) which was $82 \mathrm{~mm}$.

The gas evolution curve from the mixture (MWF-PKW) showed a H'm $(68.4 \mathrm{~mm})$ higher than that of the wheat flour $\left(\mathrm{H}^{\prime} \mathrm{m}=65.1 \mathrm{~mm}\right)$. This value was obtained in a shorter time T ' $1(1 \mathrm{~h} 04 \mathrm{~min} 30 \mathrm{~s})$ compared to wheat flour (T’1 = $1 \mathrm{~h} 55 \min 30 \mathrm{~s})$.

The total gas volume $(1566 \mathrm{ml})$ was higher than the wheat flour $(1448 \mathrm{ml})$, and was sufficient to raise the dough. A small amount of the gas was lost ( $99 \mathrm{ml})$ due to a strong retention capacity of the mixture $(1467 \mathrm{ml})$, whose coefficient was $93.7 \%$ compared to $92.2 \%$ for the wheat flour. The Falling Number of the mixture ( $\mathrm{FN}=328 \mathrm{sk}$ ) was lower than that of the control wheat flour ( $\mathrm{FN}=370 \mathrm{~s}$ ). This difference could be from higher enzymatic activity in the mixture because of more amylases. This study shows that the watermelon puree could be used by bakers or millers to correct batches of hypodiastaticemo wheat flours with a high Falling Number (over $400 \mathrm{~s}$ ) from a lack of enzymes.

Keywords: Wheat flour; watermelon puree; bread making; fermentation; rheological properties

\section{Introduction}

Bread making is the technical process that transforms wheat flour into bread. Wheat flour is the main ingredient in bread making throughout the world and obtained from the milling of wheat kernels (Triticum aestivum L) [1]. Wheat flour contains gluten, a protein that can form a network of retained carbon dioxide resulting from the release of fermented carbohydrates through the action of amylases from yeasts (Saccharomyces cerevisiae), ultimately allowing the bread dough to rise $[2,3]$. Gluten also gives the moistened bread dough its capacity of extensibility, elasticity and toughness during the baking process $[4,5]$. This means that fermentation is an important step in the bread production process and this can be achieved with amylases provided by yeasts into the bread dough. Amylases can be obtained from several sources, such as plants [6]. It has been shown that watermelon is an excellent source of sugars and amylases [7, 8]. Furthermore, watermelon is rich source of nutrients such as lycopene, vitamins, L-citrulline and L-arginine which play an important role in human metabolism [9-11]. In our previous study, we showed that incorporation of lycopene and L-citrulline into bread is of nutritional interest [12]. Watermelon is highly nutritional and offers a means to incorporate lycopene, L-citrulline and L-arginine into diets [13]. In recent years, various studies have shown a functional capacity of those nutrients to reduce the risk of cancers, heart disease, diabetic vascular dysfunction and sarcopenia, a pathology characterized by a decreased muscle mass in the elderly [10,14-17] . The objective of this study was therefore to investigate the processing quality of watermelon puree in bread making. This is all the more important given that there is a lack of watermelon processing technology in many developing countries. In fact, packaged watermelon products are still rare in most countries [10]. This will also help to diversify the use of watermelon by creating added value that will benefit consumers. 


\section{Material and Methods}

\section{Plant Material}

Red-fleshed watermelons were grown from seed in greenhouses and seedlings transplanted one week after germination to the Senegalese Agricultural Research Institute plots in Dakar (Senegal). At maturity, watermelons were harvested and stored in a cold place (at $15^{\circ} \mathrm{C}$ ) for three days. In this study, a "Kaolack" (KK) watermelon variety has been chosen according to the maturity criteria which are basically the heaviness and the sound of the fruit after tapping. The fruit was not be affected by any diseases.

\section{Watermelon Treatment}

First watermelon was cleaned and completely hollowed, all components of the fruit (flesh, peels, juice, and seeds) except rinds collected. Flesh was cut into small pieces to facilitate grinding. After two to three minutes of grinding using a Waring Commercial Blender (Model 24 CB), a red watermelon solution consisting of a mixture of juice, flesh and seeds was obtained. The grinding was repeated three times. The watermelon solution was filtered in order to separate watermelon juice and puree. Filtration was carried out using a sieve (ASTM-E11 Prüf-Sieb) with an opening diameter of three $\mathrm{mm}$ and allowing only the watermelon juice to pass through.

\section{Packing and conservation of the watermelon puree}

Before use, pureed watermelon was stored cold $\left(6^{\circ} \mathrm{C}\right)$. Puree was poured into $60 \mu \mathrm{m}$ thick high density black polyethylene (HDPE) bags designed to resist tearing and moisture uptake [18].

\section{Wheat Flour Characteristics}

The study was conducted using commercial wheat flour (Type 65) according a French Classification for flour (based on the mineral content after burning) with mineral content between 0.62 and $0.75 \%$ [19]. Wheat flour was purchased from local market at Dakar and stored in its original packaging at room temperature $\left(25^{\circ} \mathrm{C}\right)$ until used.

\section{Dough Production and Kneading}

A mixture composed by wheat flour (95\%) and puree from KK watermelon variety (5\%) (MWF-PKW) was made. In a kneader tank, $250 \mathrm{~g}$ of ingredients (wheat-watermelon) was mixed for one minute and then with a spatula, the flour particles that stick on the inner walls of the tank were put back in the mixture so that all the dough was well hydrated. After this last operation, the kneader was re-started for six minutes in which $1 \mathrm{~g}$ of salt has been added gradually to the dough. A control sample $(100 \%$ wheat flour) was produced. From the beginning of the kneading,

\section{Fermentative Ability of Wheat Flour-Watermelon Puree Mixture}

The rheofermentometer is one of the most modern devices used for the assessment of wheat flour technological quality
[20]. In this study, the fermentability of the mixture (MWF-PKW) was determined using a Chopin Rheofermentometer (Rheo F4), thus the carbonic gas ( $\mathrm{CO} 2)$ production of the dough during the fermentation was evaluated. The kneaded dough was introduced into the rheofermentometer, tamped by hand and distributed until its height was below the first lower holes of the device. After this operation, the load of $2 \mathrm{Kg}$ was put on the piston as defined for the Chopin protocol. The piston was placed on the paste and the aluminum basket in the rheofermentometer tank. Finally, the displacement sensor was placed and the assembly hermetically closed. The rheofermentometer displayed the dough development and gas evolution curves as well as a table summarizing the most important data.

The following parameters have been measured: $\mathrm{Hm}(\mathrm{mm})$, the maximum development of the dough ; $\mathrm{h}(\mathrm{mm})$,height of the dough at the end of the test; $(\mathrm{Hm}-\mathrm{h}) / \mathrm{Hm}(\%)$, indicator of the decrease of dough development; T1 (s),time required for the maximum development of the dough; H'm (mm), maximum height of gas evolution; T'1 (s), time required for the maximum gas evolution; $\mathrm{Tx}(\mathrm{s})$, porosity onset time of dough; Total volume (ml), total gas volume produced during the test; $\mathrm{CO} 2$ volume lost (ml), amount of the total gas lost; Retention volume (ml), amount of total gas retained; Coefficient of retention (\%), ratio between the volume retained in the dough and the total volume of gas produced.

It should be noted that all the tests were carried out with demineralized water and the same protocol has been applied for the control sample.

\section{The Falling Number Measurement}

The falling number of the mixture (wheat / watermelon) was measured. The Falling Number (FN) is a technique based on the viscosity state of a starch gel obtained from $7 \mathrm{~g}$ of flour with $25 \mathrm{ml}$ of water [21]. This mixture is introduced into a test tube, immersed in a water bath. The time taken by a piston to fall to the bottom of this tube is measured in seconds; the less the starch is degraded by the enzymes, the more this mixture will remain viscous and the fall of the piston will be lengthened. Conversely, the more the starch is degraded by the enzymes, the more the mixture becomes fluid, and the piston falls faster. A low FN (for example 200 seconds), indicates that the flour contains a lot of enzymes and is referred to as hyperdiastatic [22]. In contrast, if the FN is 400 seconds, the flour is hypodiastatic and is less rich in enzyme [23].

A low enzyme activity leads to a minimum of liquefaction of the starch and a very high capacity for water retention resulting in a high viscosity which opposes the lifting of the dough under the effect of the gas thrust [24]. The normal value sought for baking is between $240-280$ seconds. A very short FN leads to a formation of sticky dough and bread that lacks holding while a FN that is too long corresponds to a slow fermentation, insufficiently developed bread and a pale crust [25]. 


\section{The Bread Making Tests}

The Bread Making Tests were conducted at ITA's Experimental Bakery

A mixture (500g) composed of wheat flour (95\%) and watermelon puree (5\%) from Kaolack watermelon variety were made. Those ingredients were weighed and mixed for one minute using a kitchen blender. After this operation, the kneader was re-started in which salt $(9 \mathrm{~g})$, yeast $(5 \mathrm{~g})$, water $(250 \mathrm{~g})$ and bread improver $(2 \mathrm{~g})$ were added gradually to the dough. Ingredients were mixed for 10 minutes, in order to obtain a smooth and homogeneous dough. Three tests were performed. A control sample $(100 \%$ wheat flour) was produced following the same protocol.

For each test, two samples of $250 \mathrm{~g}$ were weighed from homogeneous dough and left to rest for 10 minutes. The fermentation of doughs was the last step before baking in the oven, it was carried out for 65 minutes. After fermentation, samples were put in a rotary baking oven equipped with a steam injection system for 25 minutes at $200^{\circ} \mathrm{C}$. The breads volume and weight were measured after two hours of rest at room temperature $\left(25^{\circ} \mathrm{C}\right)$ using a volumeter equipment (CHAUPIN France) and an electronic kitchen scale BC 5000V1Type 5280 (TEFAL, France) respectively. Data are presented as the mean \pm SD. Analysis of Variance ANOVA was performed on the mean values to determine the significance of any differences between samples $(\mathrm{p}<0.05)$ using XLSTAT-Pro 6.1.9

\section{Results and Discussion}

The fermentative properties of MWF-PKW are presented in Table 1. Hm (81.9 $\mathrm{mm}$ ) represents the maximum dough height and this quantity is correlated with the volume of the breads resulting from the mixture and is close to the $82 \mathrm{~m}$ of the reference $(100 \%$ wheat flour). The height of the dough at the end of the test $\mathrm{h}(81.4 \mathrm{~mm})$ and the time required for the maximum development of the dough, with respect to the enzymatic activity of the yeasts contained therein $\mathrm{T} 1(2 \mathrm{~h} 58 \mathrm{~min} 30 \mathrm{~s})$ were satisfactory compared to those of wheat flour $(\mathrm{h}=82 \mathrm{~mm}$ and T1 $=3 \mathrm{~h}$ ). These results were materialized by the development curve which presented a correct dough height $(\mathrm{Hm})$, a small decrease of development $(0.6 \%)$ and a good tolerance, justified by the absence of T2, which is an indicator of the tolerance of a dough during fermentation Figure 1.

The gas evolution curve from the mixture (MWF-PKW) showed a H'm $(68.4 \mathrm{~mm})$ greater than that of the wheat flour $\left(\mathrm{H}^{\prime} \mathrm{m}=65.1 \mathrm{~mm}\right)$ Figure 2 . This value was obtained in a shorter time T '1 (1 h 04 min $30 \mathrm{~s}$ ) compared to wheat flour ( $\mathrm{T}$ '1 = $1 \mathrm{~h}$ $55 \mathrm{~min} 30 \mathrm{~s})$. The total gas volume $(1566 \mathrm{ml})$ was higher than the wheat flour ( $1448 \mathrm{ml}$ ). This was sufficient to raise the dough, especially since a small amount of the gas was lost $(99 \mathrm{ml})$ due to the strong retention capacity of the mixture $(1467 \mathrm{ml})$. The retention coefficient of the mixed flour dough was $93.7 \%$ while that of the wheat flour was $92.2 \%$.

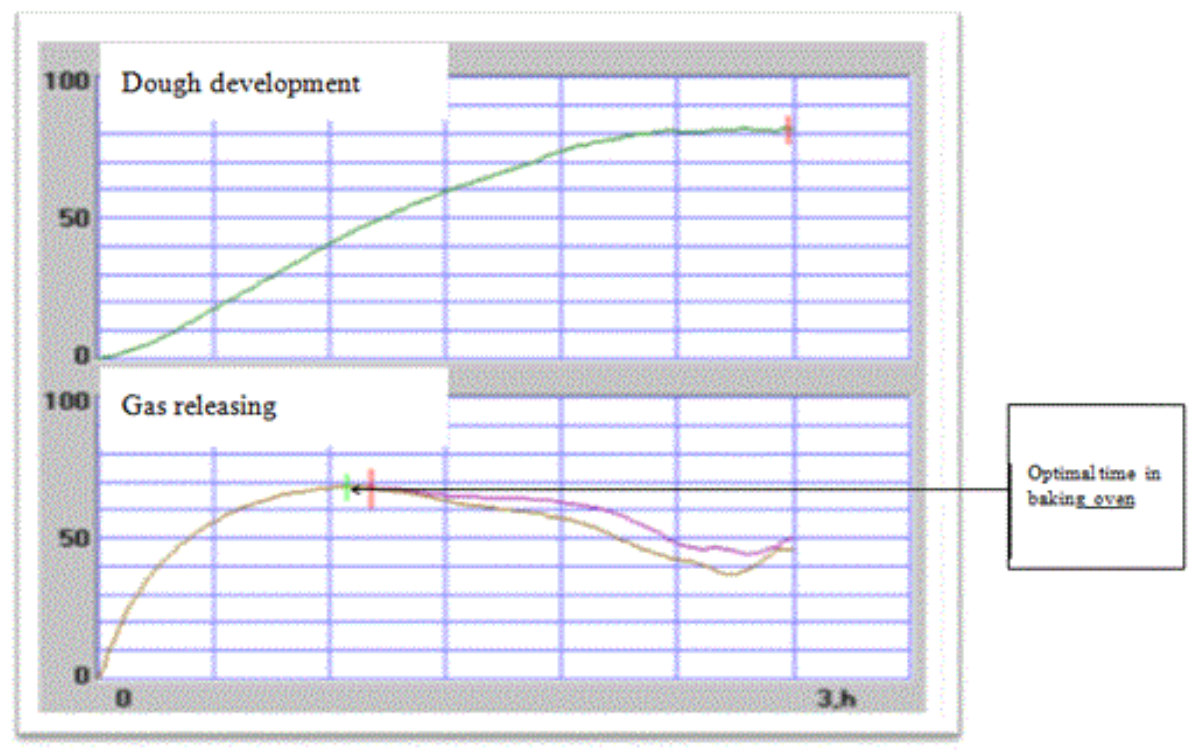

Figure I: Dough development and gas production and (mixture 95\% wheat and 5\% puree kk) 


\begin{tabular}{|c|c|c|c|c|c|c|c|c|c|c|c|c|}
\hline \multirow[b]{2}{*}{ Samples } & \multicolumn{4}{|c|}{ Dough development } & \multicolumn{7}{|c|}{ Gas releasing } & \multirow{2}{*}{$\begin{array}{c}\begin{array}{c}\text { Viscosity } \\
\text { state }\end{array} \\
\text { Falling } \\
\text { Number } \\
\text { (s) }\end{array}$} \\
\hline & $\begin{array}{l}\mathrm{Hm} \\
(\mathrm{mm})\end{array}$ & $\begin{array}{c}\mathrm{H} \\
(\mathrm{mm})\end{array}$ & $\begin{array}{c}(\mathrm{Hm}- \\
\text { h) } / \mathrm{Hm} \\
(\%)\end{array}$ & $\begin{array}{l}\mathrm{T} 1 \\
\text { (s) }\end{array}$ & $\begin{array}{l}\mathrm{H}^{\prime} \mathrm{m} \\
(\mathrm{mm})\end{array}$ & $\begin{array}{l}\mathrm{T}^{\prime} 1 \\
(\mathrm{~s})\end{array}$ & $\operatorname{Tx}(\mathrm{s})$ & $\begin{array}{l}\text { Total } \\
\text { volume } \\
(\mathrm{ml})\end{array}$ & $\begin{array}{c}\mathrm{CO}_{2} \\
\text { volume } \\
\text { lost }(\mathrm{ml})\end{array}$ & $\begin{array}{l}\text { Retention } \\
\text { volume } \\
\text { (ml) }\end{array}$ & $\begin{array}{l}\text { Coefficient } \\
\text { of } \\
\text { retention } \\
(\%)\end{array}$ & \\
\hline $\begin{array}{c}\text { Mixture } \\
\text { (95\% wheat } \\
\text { flour 5\% } \\
\text { watermelon } \\
\text { puree) }\end{array}$ & 81.9 & 81.4 & 0.6 & 10710 & 68.4 & 3870 & 4230 & 1566 & 99 & 1467 & 93.7 & 328 \\
\hline $\begin{array}{c}\text { Wheat flour } \\
-100 \%\end{array}$ & 82.0 & 82.0 & 0 & 10800 & 65.1 & 6930 & 8280 & 1448 & 113 & 1335 & 92.1 & 370 \\
\hline
\end{tabular}

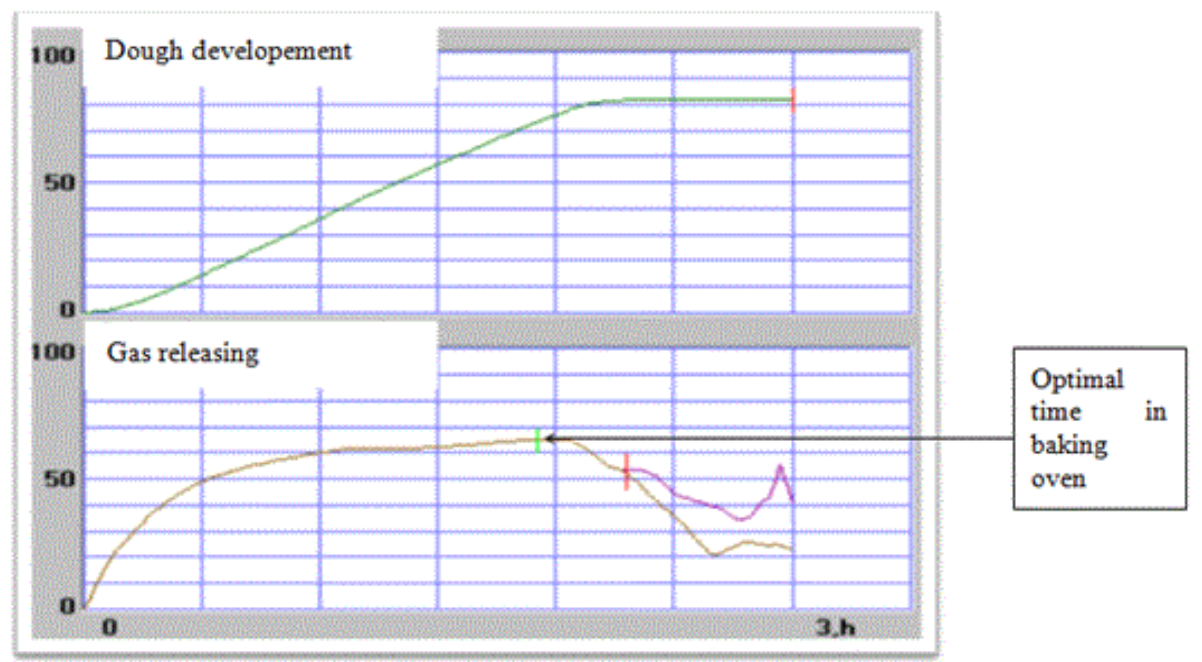

Figure 2: Gas production and dough development (100\% Wheat flour)

The retention coefficient $(\mathrm{R})$ is defined as the ratio between the volume retained in the dough and the total volume of gas produced during the test. The porosity onset time $(\mathrm{Tx}=1 \mathrm{~h}$ $10 \mathrm{~min} 30 \mathrm{~s}$ ) of the dough resulting from the mixture was also satisfactory. Porosity onset time is the moment when the dough begins to release $\mathrm{CO}_{2}$ and this time is closely related to the amount of gas lost and the coefficient " $\mathrm{R}$ ". These results can be explained by a low level of damage to the starch grains of wheat flour while the addition of the watermelon puree increased the viscosity of the mixture and gas retention and therefore the optimization of the baking time reported that heated watermelon juice at $90^{\circ} \mathrm{C}$ has a higher viscosity. In the same way, the watermelon puree could increase the viscosity of this mixture [26]. These results are materialized by the gas evolution curve of the mixture which shows that the dough of this mixture has a good processing quality in bread making.

Overall, the results of the fermentability tests of this mixture showed that the wheat flour and watermelon puree mixture can yield a dough from which quality breads can be obtained.

A 5\% watermelon content in the bread mixture would contribute $0.6 \mathrm{mg}$ lycopene and $30 \mathrm{mg}$ citrulline and arginine. The use of pureed watermelon may have several advantages in addition to the nutritional benefit (lycopene, L-arginine and L-citrulline bread fortification) in bread, including the reduction of the dough porosity, increased gas production during fermentation, gas retention and optimization of baking oven loading time. The Falling Number of the mixture $(\mathrm{FN}=328 \mathrm{~s})$ is lower than that 
of the control wheat flour ( $\mathrm{FN}=370 \mathrm{~s}$ ). This difference could be explained by the fact that the mixture has a greater enzymatic activity because it contains more enzymes (amylases). It has been reported that a short FN reflects high amylase activity [27]. Thus, the amylases contained in the watermelon puree contributed to the lowering of the Falling Number of the mixture. The difference in the FN between samples can also be explained by the addition of carbohydrates from the watermelon puree which would increase substrate for enzymes. The mixture had a good amylase activity for bread making, that means that the fermentation went well and lead to good quality bread.

This study shows that the watermelon puree could be used by bakers or millers to correct batches of hypodiastatic wheat flours with a high Falling Number (over $400 \mathrm{~s}$ ) because they do not contain enough enzymes. Wheat flour with a very long FN gives insufficiently developed breads due to the slow fermentation of the dough [25]. In this regard, the addition of watermelon puree thanks to its vegetable amylase supply could constitute an alternative to the addition of barley malt to shorten a very long FN. Nonetheless, a high rate of incorporation of watermelon puree could lead to a hyperdiastatic mixture by increasing the enzymatic activity; this can have negative consequences in bread making [25]. Results of breads measurements are presented in Table 2. The bread making tests showed that the mixture of wheat flour $(95 \%, 5 \%)$, and Kaolack watermelon puree presented a good processing quality.

\begin{tabular}{|c|c|c|}
\hline \multicolumn{2}{|c|}{ Table 2: Bread's characteristics } \\
\hline Dough sample & $\begin{array}{c}\text { Bread } \\
\text { volume } \\
\left(\mathrm{cm}^{3}\right)\end{array}$ & Bread weight (g) \\
\hline Mixture (95\% wheat flour 5\% & $\begin{array}{c}\text { 973.33 } \pm \\
62.82^{\mathrm{a}}\end{array}$ & $198.33 \pm 1.97^{\mathrm{a}}$ \\
\hline watermelon puree) & $1076.67 \pm$ & $202.83 \pm 2.92^{\mathrm{b}}$ \\
\hline Wheat flour (100\%) & $49.67^{\mathrm{b}}$ & \\
\hline
\end{tabular}

Values are means \pm SD

Means within columns with different letters are significantly different at $\mathrm{P}<0.05$

However, the volume of bread obtained from the mixture $(973.33$ $\pm 62.82 \mathrm{~cm} 3)$ and the control sample ( $100 \%$ wheat flour $)(1076.67$ $\pm 49.67 \mathrm{~cm} 3)$ are significantly different $(\mathrm{p}<0.05)$. It is the same for the breads weight, results are significantly different $(\mathrm{p}<0.05)$ between the mixture $(198.33 \pm 1.97 \mathrm{~g})$ and the control $(202.83$ $\pm 2.92 \mathrm{~g}$ ). This observation can be explained by the amount of watermelon puree added in the mixture whose nutrient content is quantitatively and qualitatively different from that of wheat flour.

Future research should be focused more on all alveographic parameters and particularly nutrients (lycopene, L-citrulline, L-arginine, vitamins, minerals) or fermentable sugars contents of the mixture wheat flour-watermelon puree as this new technical approach could add unusual nutrients to improve the nutritional quality of breads. The sensory evaluation should be conducted concurrently with panelists in order to investigate if bread obtained from wheat flour and watermelon puree mixture will be liked. Additionally, in order to optimize the mixture dough formulation, all rheological tests should be carried out in triplicate with statistical analysis for more detail and precision. The aim of this study is to present a brief synopsis about the need

\section{Conclusion}

This paper presents the use of watermelon puree (PW) in bread making. Results suggest that the mixture of wheat flour (WF) and PW has a strong fermentative ability. Results also suggest that PW could be used by bakers or millers to correct batches of hypodiastatic WF with a high Falling Number (FN) because they do not contain enough enzymes. In consequence, PW could be used as an alternative to the addition of barley malt to shorten a very long FN. Additionally, the incorporation of PW in WF may increase nutrients such as vitamins, lycopene, L-citrulline, L-arginine, vitamins and minerals in breads.

\section{Acknowledgement}

The authors gratefully acknowledge the valuable technical assistance of Mokhtar SAMB, Maurice S LOPY, Aïssatou Ngom NDIAYE and Babacar BEYE at "Institut de Technologie Alimentaire" (Dakar, Senegal), Youga NIANG at CDH/ISRA (Senegal).

\section{References}

1. Horváth C. Storage proteins in wheat (triticum aestivum l.) and the ecological impacts affecting their quality and quantity, with a focus on nitrogen supply. Columella - Journal of Agricultural and Environmental Sciences. 2014;1(2):57-76.

2. Ali A, A Shehzad A, Khan MR, Shabbir MA, Amjid MR. Yeast, its types and role in fermentation during bread making process-A Review. Pak J Food Sci. 2012;22(3):171-179.

3. Struyf N, Van der Maelen E, Hemdane S, Verspreet J, Verstrepen KJ, and Courtin CM. Bread Dough and Baker's Yeast: An Uplifting Synergy. Comprehensive Reviews in Food Science and Food Safety. 2017;16(5): 850-867.

4. Pečivová $P$, Pavlínek V, Jan Hrabě J. Changes of properties of wheat flour dough by combination L-ascorbic acid with reducing or oxidising agents. Acta Chimica Slovaca. 2011;4(2):108-117.

5. Patil S and Arya SS. Optimization and characterization of glutenfree formulation for the development of guten free flatbread using underutilised sources. Curr Res Nutr Food Sci Jour. 2018;6(3):678689.

6. Yalçın H T, Çorbacı C. Isolation and Characterization of Amylase Producing Yeasts and Improvement of Amylase Production. Turk J Biochem. 2013;38(1):101-108. doi: 10.5505/tjb.2013.95866

7. Menon S V, Rao T V R. Enzyme activities during the development of ripening of watermelon (Citrullus lanatus (Thunb.) Matsum. Nakai) Fruit. International Journal of Plant Developmental Biology. 2012;6 (1):21-26.

8. Sabeetha S, Amin I, Nisak MYB. Physico-chemical characteristics of watermelon in Malaysia. J Trop Agric and Fd Sc. 2017;45(2):209-223.

9. Perkins-Veazie P, Collins JK, Pair SD and Roberts W. Lycopene content 
differs among red-fleshed watermelon cultivars. J Sci Food Agri. 2001;81(10):983-987.

10. Maotoa MM, Beswa D , Jideani AIO. Watermelon as a potential fruit snack.International Journal of Food Properties. 2019;22(1):355370 .

11. Collins JK, Wu G, Perkins-Veazie P, et al. Watermelon consumption increases plasma arginine concentrations in adults. Nutrition.2007;23(3): 261-266.

12. Sadji M, Ndiaye NF, Lopy MS, et al. Production of Puree and Watermelon (Citrullus lanatus) Juice Usable in Bread Making. J Food Nutr Popul Health. 2018; 2(1):11-3.

13. Erhirhie EO, Ekene NE. Medicinal values on Citrullus lanatus (Watermelon): Pharmacological Review. International Journal of Research in Pharmaceutical and Biomedical Sciences. 2013;4:13051312.

14. Naz A, Butt MS, Sultan M, Qayyum MMN, Shahid Niaz RS. Watermelon lycopene and allied health claims. EXCLI J. 2014;13:650-666.

15. Allerton TD, Proctor D, Stephens JM, Dugas TR, Spielmann G, Irving BA. L-Citrulline Supplementation: Impact on Cardiometabolic Health. Nutrients. 2018;10(7): pii: E921. doi: 10.3390/nu10070921

16. Tsuboi T, Maeda M, Hayashi T. Administration of L-arginine plus L-citrulline or Lcitrulline alone successfully retarded endothelial senescence. PLoS ONE. 2018;13(2):e0192252. doi: 10.1371/journal. pone. 0192252

17. Dhillon RJS, Hasni S. Pathogenesis and Management of Sarcopenia. Clin Geriatr Med. 2017;33(1):17-26. doi: 10.1016/j. cger.2016.08.002

18. Hussein AA, Salim RD and Sultan AA. Water absorption and mechanical properties of high - density polyethylene/ egg shell composite. Journal of Basrah Researches (Sciences). 2011;37(3A):36-
42.

19. Bourre J-M, Bégat A, Leroux Ma-C, Mousques-Cami V, Pérardel N, Souply F. Valeur nutritionnelle (macro et micro-nutriments) de farines et pains français. Med. Nut. 2008;44(2):49-76.

20. Codină GG, Mironeasa S, Daniela V, Voica DV and Mironeasa C. Multivariate Analysis of Wheat Flour Dough Sugars, Gas Production, and Dough Development at Different Fermentation Times. 2013;31(3):222-229.

21.Dangi P, Khatkar BS. Physicochemical and Gluten Quality Characteristics of Commercial Wheat Varieties. International Journal of Innovative Research in Science, Engineering and Technology. 2017;6(7):13448-13454.

22. He Y, Lin YL, Chen C, Tsai MH, and Lin AHM. Impacts of Starch and the Interactions Between Starch and Other Macromolecules on Wheat Falling Number. Comprehensive Reviews in Food Science and Food Safety. 2019;18(3):641-654.

23. Ral1 JP, Whan A, Larroque O, Leyne E, Pritchard J, Dielen AS, et al.. Engineering high a-amylase levels in wheat grain lowers Falling Number but improves baking properties. Plant Biotechnol J. 2016;14(1):364-376. doi: 10.1111/pbi.12390

24. Balla A, Blecker C, Oumarou M, Paquot M, Deroanne C. Mise au point de pains composites à base de mélanges de farines de sorgho-blé et analyse texturale. Biotechnol. Agron Soc Environ. 1999;3(2):69-77. 25. Lachance P. Lřindice de chute (Hagberg). Agri-Vision. 2004.

26. Ye Liu , Song H, Yang X, He C. Influence of multiple environmental factors on the quality and flavor of watermelon juice. RSC Adv. 2019;9:15289-15297. DOI: 10.1039/C9RA01533G

27. Azokpota P, Sindic M, Paquot M, Deroanne C. Rheological properties of bread flour made from starch extracts and wheat gluten extracts. J Biol Chem Sci. 2010;4(5):1582-1592. 